\title{
ld Norse gods in contemporary Norwegian
novels
}

\section{Cristina Vişovan}

Babeş-Bolyai University, Cluj-Napoca, E-mail:cristinas8@yahoo.com

\begin{abstract}
:
Old Norse mythology is one of the most prolific fields in modern times. From a scholarly renewed interest to a more popular based reception, the old myths and gods seem to have been revived. The following article deals with the representation and role of two of the Old Norse gods, Odin and Ty, in contemporary Norwegian literature. It discusses in a comparative way the image of the Old Norse gods as presented by the written sources about the Viking mythology, The Poetic Edda and The Prose Edda, and by the contemporary novels that have them as main characters. Contemporary problems that trouble the Norwegian society seem to find their expression in literature where the old gods are presented as driven by anger and a desire to take revenge, either because they have lost their power or because they are led by a sense of duty, integrity and doing what is right. In the so called age of globalization, the Norwegian writers that use Old Norse mythology as inspiration seem to be themselves driven by a feeling of nostalgia after a time when the society was more homogenous or by a desire to promote and live by the Viking values
\end{abstract}

\section{Rezumat:}

Mitologia nordică este unul dintre cele mai prolifice domenii în perioada modernă. De la un interes reînnoit pe plan ştiințific, la o recepție ancorată mai mult în cultura populară, vechile mituri pare să fie reactualizate. Articolul următor discută reprezentarea şi rolul a doi dintre zeii nordici, Odin şi Ty, în literatura contemporană norvegiană. El prezintă într-o manieră comparativă imaginea zeilor nordici aşa cum reiese din sursele scrise ale mitologiei vikinge, Edda Poetică şi Edda în proză, şi din roamanele contemporane care îi au ca personaje principale. Probleme contemporane care marchează societatea norvegiană par să-şi găsească expresia în literatură, acolo unde vechii zei sunt prezentați ca fiind conduşi de mânie şi o dorință de a se răzbuna, fie pentru că şi-au pierdut puterea sau pentru că sunt mânați de un sens al datoriei, integritate şi a face ceea ce este corect. În aşa numita eră a globalizării, scriitorii norvegieni care folosesc mitologia nordică drept inspirație par să fie ei înşişi stăpâniți 
de sentimente de nostalgie după o epocă în care societatea era mai homogenă sau de o dorință de a promova şi a trăi după valorile vikinge.

Keywords: Old Norse mythology, Odin, Tyr, nationalism, white racism, Viking virtues

\section{Introduction}

Contemporary people seem to be fascinated by the image of the bloodthirsty Viking warrior and the so called 'macho' culture of the Viking Age. Television series, Hollywood movies, theatre pieces, cartoons, books, black-metal songs, all focus on the idea of the pagan Viking warrior who sailed abroad in order to enrich himself and conquer new lands through strength and violence. Since the Viking Age was a great time for the Nordic people it is no wonder that popular culture cultivates the above mentioned representation of the Vikings.

In Norway, the Viking Age and its pagan beliefs were used during the $19^{\text {th }}$ century as a mould for creating a national identity. Nowadays people still rely on the Viking trope- the souvenir shops are full of Viking clichés, people and place names bear traces of Viking influence, we can even talk about Viking groups in Modern Norway which promote the Viking history and culture or religious groups which have revived the Viking pagan religion. ${ }^{1}$

When it comes to literature, few Norwegian writers dared to use the Viking legacy after the Nazi misuse of the Old Norse mythology but it looks as if the situation has recently changed. Several novels have been published since the turn of the century that concentrate either on the history of the Vikings or on the Old Norse mythology: Roy Jakobsen Frost (2003); Cornelius Jakhelln Gudenes Fall (The Fall of the Gods, 2007); Andreas Bull Hansen Jotnens hjemkomst (The Return of the Jotun, 2010), Før de ni verdener styrter (Before the Nine Worlds Crash, 2011), Ragnarok (2012), Jomsviking (The Jom Viking, 2017); Agnes Ravatn Fugletribunalet (The Bird Tribunal, 2013); Siri Pettersen Odinsbarn (Child of Odin, 2014); Jan Ove Ekeberg Den siste vikingkongen (The last Viking King, 2016). This testifies in favour of a

\footnotetext{
${ }^{1}$ Hafrsfjordvikingene is for example a Norwegian group that was established in 2006 and had as a purpose to spread the Viking culture. Asatrufellesskapet Bifrost is such a religious organisation which was founded in the mid 80's and officially recognized in 1998.
} 
renewed local interest in the old historical times that so many Norwegian feel proud about, as well as in the fascinating mythology of the Vikings.

In the following article we will deal with two contemporary novels that use the Old Norse myths and gods rather than on those of a historical character, namely Cornelius Jakhelln's Gudenes fall and Andreas BullHansen's Jotnens hjemkomst. The main focus will be on the representation of the Norse gods that act as main characters in contemporary fiction and their function in the novel.

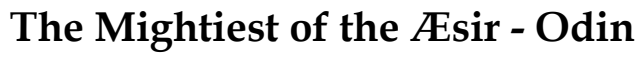

The most important written sources that we can rely on in order to get information about the Viking mythology are The Poetic Edda and The Prose Edda. The Poetic Edda is a collection of anonymous poems that are difficult to date; while some of the poems definitely deal with mythological problems, the rest focus on different heroes. These poems, together with material that hasn't survived, became the main source of inspiration for the now famous Icelander Snorri Sturlason who around 1220 created his Edda, also known as The Prose Edda. It was compiled as a handbook for Snorri's contemporary skalds at a time when the mythical language of the skaldic poetry was in danger of being lost. The book gives a whole image of the Nordic gods and their world but it cannot be used uncritically as a source for Old Norse mythology since Snorri was a Christian writing about pagan beliefs.

According to the above mentioned sources, Odin is undoubtfully the most powerful of the gods. In the eddic poem The Song of Hyndla it is said that: "He gives victory to some, to some riches,/ eloquence to many, and common sense to men; / he gives following winds to sailors, turns of phrase to poets,/ he gives manliness to many a warrior"2(Larrington 1996: 253). The Allfader (Father of All) created mankind together with Vile and Vé, while also being the father of several other gods (Thor, Balder, Hód, Váli). He is an all-encompassing deity who undertakes different roles in order to maintain the balance of power in the world and he often meets the other forces of the universe in disguise, just as one of his many names, Grim (the masked one) indicates. If

\footnotetext{
2 The Old Norse text of "Hyndlolióð” says: “Gefr hann sigr sumom, enn sumom aura,/ mælsco mǫrgom oc manvit firom;/ byri gefr hann brǫgnom, enn brag scáldom,/ gefr hann mansemi mǫrgom recci." See Edda. Die Lieder des Codex Regius Nebst Verwandten Denkmälern, Herausgegeben von Gustav Neckel, 5. verbesserte Auflage von Hans Kuhn (Carl Winter Universitätsverlag, 1983), p. 288: 3.
} 
we put together all the information that we have about Odin we get a manifold image of a powerful god who stands for war, death, poetry, knowledge, disguise, mastery of runes as well being known for his magic powers.

Most of Odin's names indicate and support the idea that he was the god of war and Lord of the Slain (Val-father). In Valhalla, he welcomed all those who died an honourable death in battle. Here the dead warriors, the so called Einherjars, trained every single day for the final cosmic battle, Ragnarok, the end of the word. But Odin is related to death also through his attempts to gain wisdom about the past and the future by talking to the dead or by offering and hanging himself in the world tree, Yggdrassil. There he hanged nine nights in order to obtain the runes which were in possession of the giants, managing to overpass the borders between life and death and returning with some new knowledge that remains secret to the readers. Wisdom again is the reason why Odin once sacrificed his eye just to take a sip from Mimir's well which "has wisdom and intelligence contained in it" 3 (Faulkes 1995: 17).

Besides wisdom Odin also succeeded in mastering seiðr (seid), a type of sorcery practised in the Norse society. Steinsland argues that seid is of a magic character to the extent that the one who performs it tries to impose through his own will. Those who practised it were both feared, respected and despised but in some cases seid was connected to the higher strata of the society and that is why Odin was also related to it (Steinsland 2005:307). As one who always wanted to find out more, Odin learnt how to practise seid so that he could come in contact with the powers on the edges of the universe.

He was also known as the best poet among the gods since he had once stolen the mead of poetry from the giants by seducing the giant woman, Gunnlod (daughter of Suttung), who was guarding it. As a reward for spending three nights with her, Odin demanded a drink from the precious mead for each night they had spent together and then "He left Suttung betrayed at the feast/and made Gunnlod weep"(Larrington 1995: 29 ) by stealing the whole drink, changing into an eagle and flying back to Åsgard ${ }^{4}$.

\footnotetext{
3 The Old Norse text says: “...er spekð ok manvit er ifolgit..." See Sturluson Snorri. Edda, Udgiven af Finnur Jónsson (Gads Forlag, 1926), p. 20-21.

4 In "Hávamál it says: " Suttung svikinn hann lét sumbli frá/ oc grætta Gunnlǫðo." See Edda. Die Lieder des Codex Regius Nebst Verwandten Denkmälern, Herausgegeben von Gustav Neckel, 5. verbesserte Auflage von Hans Kuhn, (Carl Winter Universitätsverlag, 1983), p. 34: 110.
} 
Snorre presents Odin as the ancestor of several ruling families in Denmark, Norway, Sweden, The British Isles as well as on the Continent (Faulkes 1995: 4-5) and creates a correlation between the Old Norse god and power. The kings and rulers often identified themselves as sons of Odin and their mythological based genealogy was used as a way to claim and affirm their status in society.

Unsurprisingly Odin has been the Norse god that scholars have paid most attention to. Together with his central function in the old pagan mythology these seem to be sufficient arguments for his resurfacing as a character in contemporary Norwegian novels.

\section{The nostalgic/nationalistic Odin}

Cornelius Jakhelln is a Norwegian writer and musician who uses Old Norse mythology as inspiration. In 2007 he published his first novel, Gudenes fall, which won the prize for the best contemporary Nordic novel in 2007, as well as the prize for the best Norwegian work in the field of fantasy in 2008. The main character of the novel is Odin who is depicted as having lost his power with the coming of Christianity and his exile, in Underheimen, a world situated under that of the humans; "They (the humans) live up there in Midgard, above the sky that separates us, unaware of the divine reality that is their ancestry." ${ }^{5}$ It is a symbolic place which reflects how the old pagan religion is viewed nowadays; the Old Norse gods still exist in our consciousness but they represent a religion that, for the most of us, is no longer alive.

The Lord of Valhalla feels bitter for having been chased under the ground like a beetle because today, he has nothing left of his former mightiness. Instead of being called The Highest because of his power, the other gods still call him that way but based on his height. Rather than being represented as the all-encompassing Old Norse god, Odin resembles a contemporary human being; he drinks whiskey and espresso, smokes, eats chocolate, listens to black-metal music and likes to philosophize alone. Precisely because he spends so much time alone, Odin has lost the others' consideration as well as his former status. "Here where I sit I feel ashamed

\footnotetext{
${ }^{5}$ Our translation of: “Di lever der oppe i Midgard, over himmelen som sjiller oss, uvitene om den gudommelige virkeliheten vor di har sit opphav." See Cornelius Jakhelln, Gudenes fall (J.W. Cappelens Forlag AS, 2007), p. 37.
} 
because of my lack of power. The power is gone, shame is all I own." $6 \mathrm{He}$ feels ashamed because of his non- intervention politics at the time when Christianity came and the humans sent the gods under the ground. The old mighty Odin has been reduced to the status of a spectator who only watches what others do without having any decision power. He is an actor in a drama written by others but he takes comfort in the fact that passivity is better than what the humans have to endure because of the daily stress. He himself admits that:"I am called the god of the dead, the god of the hanged, a oneeyed god of wisdom, god of the skalds and of the kings. And there is not so much left of me, unfortunately, that I can live up to these designations, because I consider them to the highest degree as glorious designations and not just some meaningless memories from the past."7

In order to feel powerful again, Odin goes up on the scene and performs as a stand-up comedian and here he feels again that he is the lord of the world. But his jokes do not have the result that Odin expects, on the contrary, the other gods make fun of him and laugh at him; even his son, Tor, caricatures him. There's no place for applause or appreciation, the only thing Odin gets is mead spilt all over him. The situation is no better in the world of the humans, where Odin is remembered only through black metal bands and some new religious groups. In the end, Odin himself is aware of his tendency to "... overestimate myself, to present myself better than I actually am." 8

Odin is no longer the god of war, and despite the fact that Valhalla was also moved under the ground, in Underheimen, there has been an interdiction in entering this realm as a result of the fall of the gods after the introduction of Christianity. The humans are refused entrance in the world of the gods because that would mean the end of the Æsir. The way they handle war is seen upon by Odin as slaughter, destruction; he considers that the modern war leaders are just hateful and fight without honour or commitment as long as they use mass destruction weapons against an enemy

\footnotetext{
${ }^{6}$ Our translation of: “Her jei sitter skammer jei mei over min avmakt. Allmakta er borte, skam er alt jei eier." ( Ibid., 61)

${ }^{7}$ Our translation of: "Jeg er blitt kalt di dødens gud, di hengtes gud, en ensøys visdomsgud, gud for skalder å konger. Å så mye ijen a mei er de vel ikke, dessverre, at jeg kan leve opp te alle disse beteinelsene, for jei anser di i høyeste grad som hedersbeteinelser, ikke bare som meningsløse minner fra fortia." (Ibid., 50)

${ }^{8}$ Our translation of: "... å oppvurdere mei sjøl, te å fremstille mei som bedre enn jei egentli er." (Ibid., 50)
} 
that they cannot even see. "I no longer can be a witness to the fact that they burn small children with rockets, while the evil adults go free, hidden in their untouchable war machines." 9 Anger and rage are feelings that arise in Odin; the Norse god feels that he wants to exterminate this cowardly race that he himself once created.

He also considers it ironic that some of the humans reproduce themselves without any thoughts about how they are going to take care of and feed their children. He criticizes the 'losers' who populate the world and destroy it while it is the duty of the smarter ones, who didn't have time to have their own children, to save it. "...and when the unavoidable catastrophes knock at the door, sickness, hunger and civil war, yes, then the rat jungle must get help from those who have secured their own survival so good that they haven't had time to give birth to their own children."10

During the last thousand years Odin has felt marginalized and oppressed so he cannot stop feeling nostalgic about the past and dreaming about gaining his magnitude back: "I want to be hailed again as Odin, the ghost king, the gallows prince, lord of the revenants and of the hanged. I want to be again the father of victory that I was, the god of the war and of the warriors." 11 He feels that he has been discriminated for long enough and wants to become once again the one who suppresses others. Moreover, he no longer believes in the non-intervention politics that caused the fall of the gods because humans have proven to be tremendously good at surviving so that "... it is only a question of time before they will have killed all of nature and life." 12

The Odin of Gudenes fall is the personification of Jakhelln's own feelings towards his position inside the Norwegian society and his view of the contemporary world. As he admitted in a previous book, writing is just a way of voicing your feelings and letting go, an artistic and peaceful alternative to more violent courses of action that people who nurture similar

\footnotetext{
${ }^{9}$ Our translation of: "Jeg klarer ikke lenger å være vitne te at di brenner småbarn me raketter, mens di onne voksne går fri, der di sitter jemt i sine uinntakelie kriksmaskiner." (Ibid., 207)

10 Our translation of: "...å når di uunngåelie katastrofene banker på døra, sykdom, sult å borgerkrig, ja, da må rotteyngelen få jelp fra di som har trygga sin egen overlevelse så gått, at di ikke har hatt ti te å føde egne barn." (Ibid., 133)

11 Our translation of: "Jei vil ijen bli hylla som Odin, draugkongen, hengedrotten, jengangernes å di hengtes herre. Jei vil jeninnsettes som den Sigfader jei var, krigens å strittsmennenes gud." (Ibid., 75)

12 Our translation of: “... at de bare er et spørsmål om ti før de har drept all natur, alt liv." (Ibid., 48)
} 
feelings have chosen. ${ }^{13}$ Odin is no longer the mighty god of the Old Norse religion but an alienated and marginalized character who experiences feelings similar to those Norwegians who consider themselves immigrants in their own country. The contemporary multicultural society has replaced the homogenous society characteristic in Jakhelln's view of ancient mythical times and "The development is irreversible. The Norway of our forefathers is away forever. There remains a deep loss but also big possibilities that can be difficult to see for some of us."14

Jakhelln has also written a lot about his feelings and ideology as well as his experiences as a minoritarian white man in a certain multicultural neighborhood of Paris. There he felt his anger and rage increase and started to nurture warlike ideas directed towards young Frenchmen of Arabic and African origins. The Nordic and Germanic legacy and identity seemed a perfect refuge and a rich source of inspiration for his career both as a musician and as a writer. Odin's discourse is nationalistic and provoking since Jakhelln considers that Norway has failed to support him, as well as any other Norwegian proud of his identity. "During dark times I thought that my honor had been stepped on. That the official Norway would rather annihilate the pride I feel over my own identity." 15 He argues that many Norwegians feel marginalized in the Norwegian democracy which has opened its doors for mass immigration while at the same time hiding the racism against the white people under the carpet. He confesses: "I felt ignored, left aside, humiliated."16 In Jakhelln's opinion, all those who feel that their opinion does not count, have no other more attractive option than militant religion in today's Norway.

\footnotetext{
13 In his book, Raseri (Rage), Jakhelln mentions that he nurtured the same ideas exposed in Anders Breivik's manifest, "2083 A European Declaration of Independence”, who later killed 77 people on the 22nd of July 2011 based on his right extremist ideology. See Cornelius Jakhellen, Raseri. En hoitings forsøk på en selvbiosofi (Cappelen Damm, Oslo, 2011).

14 Our translation of: “Utviklingen er irreversibel. Våre forfedres Norge er borte for alltid. Der ligger et dypt savn, men også store muligheter det kan være vanskelig å få øye på for enkelte." See Cornelius Jakhelln, "Æren og demokratiet" Forlagsliv, https://www.forlagsliv.no/sturmgeist/2011/07/29/aeren-og-demokratiet/， par. 2, accessed at 08.08.2017.

${ }^{15}$ Our translation of: "I mørke øyeblikk har jeg tenkt at min ære er blitt tråkket på. At det offisielle Norge aller helst ville ha utslettet stoltheten jeg føler over min egen identitet." (Ibid., par. 3 )

16 Our translation of: “Jeg følte meg oversett, forbigått og krenket.” (Ibid., par. 8)
} 
Jakhelln's Odin mirrors all the above mentioned problems that have troubled him for many years because Jakhelln believes that anger is dangerous; it will once come out, one way or another. In his novel, he chooses irony and self-irony to undermine Odin's anger but, as he admits in "Æren og demokratiet", his message to the Norwegian state is that "the ticking bombs' of the society should be paid attention to and helped rather than ignored and allowed to take violent action. Nevertheless, we still have to take into account that many Norwegians consider Jakhelln's view out of place and exaggerated no matter how appreciated Gudenes fall was by the literary critics.

\section{Ty, God of War and Justice.}

Andreas Bull-Hansen is another contemporary prolific author who has published several novels that deal with either Old Norse mythology or history. On his blog he describes himself as a "traditional Viking skald, sharing the history and mythology of Norse culture", whose virtues are grounded in the Viking culture (Bull-Hansen "Author bio"). According to him, the most important characteristic of the Vikings was their integrity which Bull-Hansen describes as the ability to do what you believe is right and follow your path no matter what, because the only thing we leave behind us once we die is the memory of who we were and how we lived.

The same personal trait mentioned above defines the main character of Bull-Hansen's trilogy about the Old Norse god Tyr. Before discussing the function of Tyr in Jotnens hjemkomst (The Return of the Jotun), the first book of the trilogy, we are going to take a look at who Ty was in the old pagan mythology.

Just like Odin, Ty belongs to the family of the Æsir. In the written sources of the Nordic mythology there are only a few references to him indicating that towards the end of the pagan times he had lost some of the importance that he used to have in earlier times, as proven by other types of evidence. According to Steinsland, the Old Norse name Týr is connected to the Old German form of the name, Tiwas, that means god and appears in many kennings for other gods (Steinsland 2005: 243). ${ }^{17}$

\footnotetext{
${ }^{17}$ A kenning is a conventional poetic phrase used for or in addition to the usual name of a person or thing and common for Old Norse poetry. Among Odin's names there are Sigtýr (god of victory) and Valtýr (god of the slain).
} 
In "Gylfaginning", Snorri describes Tyr as "... the bravest and most valiant (of the Æsir) and he has great power over victory in battles. It is good for men of action to pray to him. There is a saying that a man is ty-valiant who surpasses other men and does not hesitate. He was so clever that a man who is clever is said to be ty- wise"18 (Faulkes 1995: 24). His origins are unclear and the sources give contradictory information; in "Skaldskaparmal" Snorri identifies Tyr as the battle-god, son of Odin (Faulkes 1995: 76), while in "Hymir's Poem" Tyr talks about his father, the giant Hymir, a very wise and brave man (Larrington 1996: 79). Another eddic poem, "Loki's Quarrel”, records that Loki had a son with Tyr's wife (Faulkes 1995: 91), but there is no other source that supports the idea of Tyr having a wife or an illegitimate son.

One of the few myths about Tyr tells the story of how he missed his hand as he placed it in the mouth of the wolf Fenrir, the adversary of the gods, as a pledge. The gods wanted to tie Fenrir and the only god who was brave enough to sacrifice himself for the greater good was Tyr. Tyr's willingness to offer himself fits this god's function in the field of law and justice. Snorri relates how the Æsir refused to let go of the wolf and so he bit off Tyr's hand leaving him one-handed (Faulkes 1996: 59). Later on, during the final battle, Ragnarok, Tyr fights against the evil dog Garm and they kill each other.

Like Odin, Tyr was a god of war but as opposed to the All-father who was known for his somewhat treacherous nature, he was associated with law, justice and the thing. ${ }^{19}$ Due to the fade picture that the Old Norse sources draw about Tyr, as well as the place name evidence, it seems that he may be considered an ancestor of Odin who later developed into a war god that had a strategic function, rather than being active on the battlefield. ${ }^{20}$

\footnotetext{
18 The Old Norse text says: "hann er djarfastr ok bezt hungaðr ok hann ræðr mjok sigri î orrostum; á hann er got at heita hreystimọnnum. Pat er orðak, at sá er tý-hraustr, er um fram er aðra menn ok ekki sésk fyrir. Han er ok vitr, svá at pat er ok mælt, at sá er týspakr, er vitrastr er." See Sturluson Snorri. Edda, Udgiven af Finnur Jónsson (Gads Forlag, 1926), p. 29. ${ }^{19}$ In the Old Norse society, the thing was a governing national assembly made up of the free people of the community who were presided over by law speakers.

${ }^{20}$ Bæksted argues that the three Old Norse gods that are related to battle, Odin, Tor and Ty, each represent a different aspect - Odin, the ecstasy, rage and the strategic knowledge; Tor the ruthless physical strength; and Ty the battle that was organized according to the current rules and that was perceived as the gods' valid ruling in a question of war. See Anders Bækstad, Nordiske guder og helter. Myter og sagn fra førkristen tid (Ascheoug, Oslo 2002), p. 150.
} 
Significant in this context is the fact that the Runic alphabet used during the Viking Age contained a sign that was pronounced as " $\mathrm{t}$ " and which was named after the god Ty. This rune looked like a sword or a spear $(\uparrow)$ and was symbolic for Ty's function as the god of war. According to the eddic poem the "Lay of Sigrdrifa", people had to carve victory-runes on their swords and invoke Tyr twice if they wanted to have victory (Faulkes 1996: 167). A connection between Ty and Odin and a possible argument for the theory according to which Odin is a new variant of an old god is signaled by Odin's possession of Gungnir, a spear. In the "Seeress's Prophecy", Odin flings his spear into the host and thus brings about the first war among the gods (Larrington 1996: 7).

Based on the evidence of the written sources, we could say that Tyr was a marginal god in the Old Norse mythology who becomes a main character in a contemporary Norwegian novel. This seems to be a technique widely used in contemporary re-writings in which a character that had an insignificant role in the original book, gets to be the main character in the contemporary re-writing. ${ }^{21}$ The purpose of such an endeavor is to make the reader see the story from another angle and to present extra information that could contribute to a better understanding of how things happened.

\section{Viking Values - Duty, Justice, Revenge}

Andreas-Bull Hansen makes use of the Old Norse mythology and expands the information contained by the written sources so that he creates a world in which many of the old myths can be found but in a more detailed and elaborate form. The ambiguity which surrounds the origins of the god Tyr is transposed in Jotnens hjemkomst in the fact that Tyrar, as the god is introduced in the novel, cannot remember anything about his past prior to being found under some ruins in the Muslim Chechnya.

Tyrar is described as tall, wide shouldered, with strong cheekbones, blue-grey eyes, short dark hair and a beard. Ironically (considering his mythological function as god of war), he is a war refugee who now lives in Norway where he has been successfully integrated and works as a criminal investigator. As such, he is de-mystified and recontextualized. His job is to

\footnotetext{
${ }^{21}$ Plate is one of the scholars who is preoccupied by contemporary women's rewriting and she records that starting with the 1970's we can see the development of a genre of women's writing that is rewriting the classics from the point of view of a 'marginal', usually female character, from literary history. See Liedeke Plate, Transforming Memories in Contemporary Women's Rewriting (Palgrave Macmillan, 2011), p. 6.
} 
obtain true answers from drug dealers, rapists and other types of criminals that he arrests and imprisons. He does not feel either regret or pity for them as long as he gets what he wants because Oslo is at war:

There were actually several conflicts at the same time that often merged into each other and created a bloody mixture. It was war between the Islamists in the suburbs, the Sunnite Islamists and the Shiite Islamists stabbed each other for women and kept it going through blood revenge. The rich Sikhs were at war both with the Sunnites and the Shiites and tried to chase them out of each building they bought. It was war between the Polish people and the Russians even if they fought together in the street fights against the Muslim youth. And there were also the many groups of the narcotics Mafia, pimps, human trafficants who all fought for a piece of the marked.22

We also get to know that he has a wife, Linn, and a son, Odd, who looks very much like Tyr (in contrast with the information provided by "Loki's Quarrel" where Tyr's wife is said to have an illegitimate son with Loki); just like his colleagues, he is an absent father in the sense that he isn't too much around. He suffers from a compulsive feeling of duty which governs his life; a duty in relation to his wife Linn, to whom he owes his present life, to his son Odd and to his job. At the same time he feels that he isn't good enough either for his wife or for his job, that he fails them both. His feeling is confirmed when Linn and Odd are kidnapped and killed as an act of revenge. The tragedy is nothing but a reason for Tyrar to meet Grimnes, "an old man with long grey hair and beard". ${ }^{23}$ Tyrar takes him for an informant and a fool with a rotten brain: "There were many such fools. Most of them were old hash smokers who had developed schizophrenia." 24

\footnotetext{
22 Our translation of: “Det var egentlig flere konflikter som pågikk samtidig, og som ofte blandet seg i hverandre og skapte en blodig smørje. Det var krig mellom islamistene i forstedene, sunniene og sjiaene knivet om kvinner og narko og holdt det gående med blodhevn. De velstående sikhene lå i krig med både sunniene og sjiane og forsøkte å drive dem ut av hver eneste leiegård de kjøpte. Det var krig mellom polakkene og russerne, selv om de begge sto på samme side i gateslagene mot de muslimske ungdommene. Og så var det narkomafiaens mange grupperinger, og hallikene og menneskehandlerne som alle kjempet om en del av markedet." See Andreas Bull-Hansen, Jotnens hjemkomst (Ascheoug, Oslo), p. 1819.

23 Our translation of: "en gamling, med langt grått hår og skjegg" (Ibid., 23)

24 Our translation of: " Det var mange slike som gikk omkring. De fleste var gamle hasjrøykere som hadde utviklet schizofreni." (Ibid., 25)
} 
Odin is known from the Nordic mythology as a god who travels under unknown names and the name Grimnes hints at this since it means 'the masked one'. In Bull-Hansen's novel, Grimnes travels by a car with no numbers, a modern interpretation of this god's habit of travelling incognito. The old man also seems to know many things about him that nobody should know and this fact reminds us as such of Odin, the god of wisdom. He comes to warn Tyrar that something bad is going to happen and that it is time for Tyrar to come back home. But Odin is also the god of war and death who used to allow the bravest warriors to die in battle so that they could join him in Valhalla and fight with him at Ragnarok. Consequently, when Tyrar's family is murdered, he encourages him to take revenge "It is your right. And your duty." 25

With Odin's help, Tyrar avenges the death of his family and at the same he is killed so he wakes up in Odin's home, Gladsheim. This is described as an imposing construction made of two parts - a smaller building with three-four floors and a lower building which was at least 100 meters long, Valhalla. At first he believes that he is in a hospital, then in a psychiatric institution, only to find out that he actually is a Norse god who once made a deal with the All-father. Odin helped him to get to the human world so that Ty-Ar could fulfill his love on the condition that he would bring him back when Ragnarok was close.

The rest of the novel is built on an expansion of the Old Norse myths which are sometimes modified so that they suit the story's development. One example is the above mentioned myth of how Tyr became one-handed. In Bull-Hansen's novel, it is not Fenrir who bites his arm but the Vanir god Freyr who cuts it as an act of revenge for the fact that Tyr allowed Hel to kill his grandson and for abandoning his sister, Freyia, on the night of their marriage. Nevertheless a connection is later established with the old Norse myth when we find out that the giants used to say that no man, belonging either to the Æsir or the Vanir, could have taken Tyr's arm because such powerful warriors didn't exist; "Freyr must have been helped by the Sun Swallower, the giant wolf which was going to bring the world into darkness when Ragnarok came. The Sun Swallower, the Fener wolf, Fenre, Fenris;"26

\footnotetext{
${ }^{25}$ Our translation of: “Det er din rett. Og din plikt." (Ibid., 48)

26 Our translation of: "Frøy måtte ha fått hjelp av selveste Solslukkeren, kjempeulven som skulle legge verden i mørke når Ragnarok kom. Solslukeren, Fenervarg, Fenre, Fenris;" (Ibid., 355)
} 
Tyr is torn between the recovery of his memory and his fear of forgetting Linn and Odd because in order to remain young, the gods have to eat Idun's apples which at the same time make them forget. He finds out that he was known as the warrior Jotun (giant), killer of the Vanir race, Odin's blood-red sword and leader of his army, the god to whom humans sacrificed people by spear. The revived Tyr cannot believe that he himself used to kill many Vanir during the war with the Æsir by impaling them so that the other Vanir would fear him.

Bull-Hansen's Tyr does not feel like a god at all and he feels as if none of the other gods in Åsgard are either: "Were they really gods? Was he himself a god? He didn't feel that way. A god was something omnipotent, something big and powerful. Maybe there was something godlike in Odin, he was silent and inscrutable there were he sat."27 As Tyr gradually remembers some of his past in Åsgard, he realizes that Odin does not look like the warrior that he used to be but rather like an awkward and gloomy old man who unsuccessfully tries to keep his love escapes with Freyia secret. "Loss, love, hate; such feelings are more powerful than the thirst for gold and a desire after land and richness. All the good warriors have big feelings in them... You are that way...Yes, Odin was like that before."28

While everyone admires, fears and honors him, Tyr feels like a frightened little giant boy who is afraid of the death that grows inside him, afraid of being alone in the world. It doesn't matter that the Einherjars look up at him and that the gods and most of all Odin put their faith in him, the only thing that Tyr can think about is how to find his family; he goes as far as to ignore Odin's order of bringing the treacherous Loke back to Åsgard and instead he plans a journey to Hel's realm to look for Linn and Odd. But he is no longer the powerful warrior that he used to be, the one who had no mercy, conferred no forgiveness and never surrendered. His years in the land of the humans, Midgard, have made him weak so Tyr hesitates in sacrificing Freyr's grandson in exchange for his beloved ones. Nevertheless, the two-faced Hel kills the boy herself and lays the blame on Tyr who gets

\footnotetext{
${ }^{27}$ Our translation of: "Var de virkelig guder? Var han selv en gud? Det kjentes ikke slik. En gud var noe allmektig, noe stort og mektig. Kanskje var det noe gudeaktig ved Odin, han var så taus og uutgrunnelig der han satt." (Ibid., 94)

28 Our translation of: "Savn, kjærlighet, hat; slike følelser er mektigere enn gulltørst etter land og rikdom. Alle gode krigere har store følelser i seg. Du er slik...Ja, Odin var det i hvert fall før." (Ibid., 122-123)
} 
expelled from Åsgard in order to prevent the start of a new war with the Vanir.

This isn't the first time that Tyr feels unwelcomed in Åsgard. He remembers the time when he first arrived in the land of the Æsir and how badly he was treated by the gods who made fun of him by holding their noses because he was a Jotun; they even filed his teeth so that he looked more like them. Balder still calls him "a coward puppy boy that stinks like a giant"29. For the Æsir, Tyr fought against his own people coming to be considered a traitor, he won innumerable battles while protecting their land but they cannot overcome their prejudices. ${ }^{30}$ Tyr is not one of them and he will never be, he is marginalized.

Throughout the novel Tyr is led by a sense of doing what is right for him, namely finding his wife and his son no matter what. The old Tyr went to war for Odin and for the Æsir, the new Tyr accepts to go to war again but for Linn and Odd. The eight rules that he followed during the first war against the Vanir are not valid anymore. Tyr contemplates that there is no justice in attacking people who haven't done anything; no mercy in burning their houses; no respect for other people since he only has a handful of friends left whom he despises every time he sees them drinking; no honesty in dragging his people in a war that isn't theirs for a reason that they aren't aware of, no courage in allowing others to fight for his cause; no honor or loyalty in going to war for his own interest. It is just a duty to do what is right: "But was it right for Åsgard or himself?" 31

Honor was a central concept during the Viking Age and its infringement would have asked for revenge. Instead of accepting his fate and doing nothing, the old Tyr would have done anything to regain his prestige but we know by now that the new Tyr has been softened by the years spent in Midgard. An explanation for his behavior can be found in a phenomenon encountered in our contemporary society. Thomas Andersen talks about a kind of anti-culture that has evolved, a culture in which talking about the shameful parts of one's life is considered a virtue of honesty and authenticity.32 What before was considered shameful is nowadays

\footnotetext{
${ }^{29}$ Our translation of: "en feig gutttevalp som stinker jotne. " (Ibid., 100)

30 Inai, the valkyrie that Ty Ar falls in love with, also considers that the Æsir are locked in prejudices because they do not believe that women can become warriors. (Ibid., 269)

31 Our translation of: "Men rett for Åsgard, eller ham selv?" (Ibid., 399)

32 Per Thomas Andersen is a Norwegian professor at the University of Oslo who is involved in a project called 'After Honor'. As part of this project he has given a lecture that can be
} 
appreciated; talking about subjects that were considered taboo in other times has opened the field for more tolerance, and our society is one in which tolerance is a central theme on all levels.

Despite the fact that Tyr has lost some of the sensitivity towards the Old Norse concept of honor and is represented as more tolerant, we cannot consider him a full representative of such an extreme view. He is rather the embodiment of a nostalgia after a time when anger found its expression in violence, through revenge and retribution. At the same time, the change from a merciless warrior god to a quite humane and tolerant god can be seen as symbolic for the role played by the war god in the Old Norse mythology - from a highly worshipped god some time before the Viking Age he turned into a barely present figure with few myths referring to his origins, role and endeavors. There is also a break between the moment Fenrir bites Tyr's hand off and his return and involvement in the battle at the end of the world so we could interpret the time spent by Bull-Hansen's character in Midgard as symbolic for this break since he then reappears among the gods when his help is needed at Ragnarok.

Bull-Hansen's Tyr is a symbol for the modern Norwegians. In one of his posts on the blog published on the $3^{\text {rd }}$ of April 2016, the writer underlines the fact that the Norwegians are an educated and tolerant people but we should not forget that Viking blood runs in their veins. ${ }^{33}$ His post was a result of the terrorist attack on Brussels in 2016 and the anger he felt in relation to such acts. Vengeance and duty are among the key words that Bull-Hansen uses while relating the beginnings of the criminal immigrant gangs that established themselves in Norway in the 90's and started their hellish narcotic business. They went from beating people for looking at a girl they fancied, to killing an innocent kid just because he was black; or blowing up cars in the name of an ideology. These criminals have made him feel angry so many times, angry for what they did in Norway, angry for feeling threatened just because he's white and Norwegian. He identifies them with what he calls "terrorist scumbags" and "devils" and urges the Norwegian politicians to stop building bridges to the Muslims by talking to the hate-

accessed online called "After Honor. From Egil Skallagrimsson to Karl Ove Knausgård", https://www.tsu.ge/data/file_db/scandinavian-studies/After-honor.pdf, accessed at 08.08.2017.

33 The post was later removed from Bull-Hansen's blog since it created too many heated discussions. 
speaking religious leaders and trying to find them excuses. His opinion is that nations must work together to wipe out terrorist organizations. At the same time, he, as an educated and tolerant Norwegian with Viking blood in his veins, launches a threat to these terrorists: "If we will kill our own kings for freedom, what do you think we will do to you? Use your imagination, if you have any" (Bull-Hansen, "A Message to the Terrorists"). It is obvious that Bull-Hansen considers that it is high time to stop trying to understand these terrorists since there is nothing psychological back their actions. Europe is at war and something must be done before it is too late.

Tyr is mostly driven by his sense of duty, always doing what's right for him. Nevertheless he is also full of anger: anger for losing his family, anger because Freyr cut his arm, anger because Freyia bewitched Odin and he can no longer help him get his beloved ones back and despise, hate and anger for the Vanir, a blasphemous race that did not belong either to Åsgard or his homeland, Jotunland. The Vanir of Jotnens hjemkomst are actually an allegory for the immigrant criminals and terrorists that Bull-Hansen is so worried about. No matter how tolerant Tyr has become, no matter the background reason for why he is doing it, Tyr goes to war to wipe out this despicable race because it is his duty. Once again he has to drag his people into a war that is not theirs, but only by working together can the Æsir and the giants defeat the Vanir.

\section{Conclusions}

The Old Norse gods resurface in the Norwegian literature of the $21^{\text {st }}$ century once again as main characters but this time they are de-mystified and re-contextualized. Jakhelln's Odin is no longer the mighty god that we know from the written sources dealing with the Old Norse mythology but rather resembles a human being through many of the things he does. He has lost his central status and now feels marginalized in a world that is symbolically placed under the world of the humans. He is the voice of those Norwegians who, similar to Jakhellen, feel that they have been ignored by the Norwegian government due to the pride that they feel around their national identity. Odin is an immigrant in his own country because he once accepted to be chased under the ground, a symbolic act that describes Jakekhelln's feelings towards the Norwegian government's policy of ignoring the problem of racism towards white people. But Odin is no longer an adept of the non-intervention politics and he wants to regain his 
magnitude even though that would turn him into something that he now criticizes - being an oppressor himself. In his feelings and actions Odin is led by anger which he, as well as Jakhelln, nevertheless tries to undermine through irony and self-irony.

Bull Hansen's Tyr is another representation of an Old Norse god who has a close relationship to anger and revenge. Unlike Odin, the Old Norse Tyr didn't have a very significant role during the Viking Age but he turns to be a main character in contemporary Norwegian literature. At first, he is both de-mystified and placed in the human world; but even after his re-location in Åsgard he feels marginalized by the gods for being different. He is once again the embodiment of a writer's ideology and feelings; in Bull-Hansen's view Tyr is an image for the modern Norwegians who are tolerant but who are still offsprings of the Vikings. Like Jakhelln, Bul-Hansen has felt oppressed for being Norwegian and white and he believes that the Norwegians have a duty to do what is right for them, to keep their integrity. Similarly, Tyr's duty is to find his family while at the same time he has to protect Åsgard and thus get his revenge.

Both Jakhelln and Bull-Hansen seem to be preoccupied with problems related to being white in a multicultural society as well as emotions that arise in connection with feeling discriminated and marginalized. While Odin wants to regain his supremacy and feels nostalgic about (in Jakhelln's opinion) the homogenous society of the Viking Age, Tyr has a duty of fighting off and freeing Åsgard from the despicable race of the Vanir, of taking revenge. As such, the Old Norse gods are re-written in contemporary Norwegian literature in such a way as to give voice to actual issues that trouble the Norwegian society due to the globalization of the world that we live in. 


\section{References}

\section{Primary Sources}

Edda. Die Lieder des Codex Regius Nebst Verwandten Denkmälern, Herausgegeben von Gustav Neckel, 5. verbesserte Auflage von Hans Kuhn. Carl Winter Universitätsverlag, 1983.

Bull-Hansen, Andreas. Jotnens hjemkomst. Ascheoug, Oslo, 2011. Jakhelln, Cornelius. Gudenes fall. J.W. Cappelens Forlag AS, 2007.

Sturluson, Snorri. Edda. Udgiven af Finnur Jónsson. Gads Forlag, 1926.

\section{Secondary Sources}

Arnold, Martin. Thor. Myth to Marvel. Continuum, London 2011.

Bækstad, Anders. Nordiske guder og helter. Myter og sagn fra førkristen tid. Ascheoug, Oslo, 2002.

Ellis, Davidson H.R. Gods ans Myths of Northern Europe. Penguin Books, London, 1990.

Faulkes, Anthony trans. Snorri Sturluson. Edda. Everyman, J.M.Dent, 1995. Holtsmark, Anne. Norrøn mytologi. Tru og mytar i vikingtida. Det Norske Samlaget, Oslo, 1990.

Jakhellen, Cornelius. Raseri. En hvitings forsøk på en selvbiosofi. Cappelen Damm, Oslo, 2011.

Larrington, Carolyne trans. The Poetic Edda. Oxford University Press, 1996.

Plate, Liedeke. Transforming Memories in Contemporary Women's Rewriting. Palgrave Macmillan, 2011.

Steinsland, Gro. Norrøn religion. Myter, riter, samfunn. Pax Forlag A/S, Oslo, 2005.

Turville-Petre, E.O.G. Myth and Religion of the North. The Religion of Ancient Scandinavia. Greenwood Press, Westport, Connecticut, 1975.

\section{Web postings}

Andersen, Per Thomas. “After Honor. From Egil Skallagrimsson to Karl Ove Knausgård". $\quad$ https://www.tsu.ge/data/file_db/scandinavianstudies/After-honor.pdf, accessed at 08.08.2017.

Bull-Hansen, Andreas. "Author Bio" Bjørn Andreas Bull-Hansen. https:// bull-hansen.com/whats-new/bio/, accessed at 09.08.2017. "A Message to the Terrorists" Bjørn Andreas Bull-Hansen. Retrieved from https:/ / bull-hansen.com/, accessed at 20.04.2016. 
50 | Revista Română de Studii Baltice și Nordice/The Romanian Journal for Baltic and Nordic Studies 9 (2)

Jakhelln, Cornelius. “Æren og demokratiet” Forlagsliv . https:// www.forlagsliv.no/sturmgeist/2011/07/29/aeren-ogdemokratiet/, accessed at 05.08.2017. 